\title{
Obserwatorzy uczestniczący zamiast świadków i rama zamiast obrzeży. O nowe kategorie opisu polskiego kontekstu Zagłady
}

Elżbieta Janicka

TEKSTY DRUGIE 2018, NR 3, S. 131-147

DOI: $10.18318 /$ td.2018.3.8

Elżbieta Janicka - dr, pracownica Zakładu Badań Narodowościowych w Instytucie Slawistyki PAN. Członkini redakcji pisma "Studia Litteraria et Historica". Bada wzory kultury, narracje oraz fantazmaty fundujące społeczno-kulturową prawomocność przemocy i wykluczenia. Autorka książek: Sztuka czy naród? Monografia pisarska Andrzeja Trzebińskiego (2006), Festung Warschau (2011), Janicka \& Wilczyk. Inne miasto (2013, z Wojciechem Wilczykiem), Przemoc filosemicka (2016, z Tomaszem Żukowskim).
1 Szok narracyjny to kategoria, której używa Geneviève Zubrzycki dla nazwania „wstrząsu, którego doświadczyli Polacy, gdy dowiedzieli się, że nie byli głównymi ofiarami II wojny światowej, a nawet sami popełniali wówczas zbrodnie" (G. Zubrzycki Krzyże w Auschwitz. Tożsamość narodowa, nacjonalizm i religia w postkomunistycznej Polsce, przeł. P. Tomanek, Nomos, Kraków 2014, s. 21 - wydanie amerykańskie 2006).

2 Por. R. Hilberg Perpetrators, Victims, Bystanders: The Jewish Catastrophe, 1933-1945, Aaron Acher Books, New York, NY 1992.

\section{1}

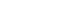


w najgorszym razie obojętność i wina obojętności. Tak prezentowała się mapa pojęć szczególnie intensywnie wykorzystywana w latach 80 . W latach 90. pojawiła się na niej dodatkowo - bezpodstawnie przeniesiona z kontekstu euroatlantyckich badań nad ocalałymi z Zagłady - kategoria traumy świadka. Wraz z nią zaś pojęcia takie jak milczenie czy utrata. Niekiedy również - zaczerpnięta z innego nieco słownika - niewyrażalność. „Traumatyczna nadbudowa" kategorii polskiego świadka Zagłady czerpała swoją prawomocność z amerykańskiego dyskursu eksperckiego, a konkretnie tej jego odmiany, która expressis verbis legitymizowała koncepcyjne przewłaszczenie. Rolę argumentu z autorytetu odegrała w tym zakresie książka Pamięć nieprzyswojona. Polska pamięć Zagłady Michaela C. Steinlaufa ${ }^{3}$.

Słowo „świadek” w odniesieniu do polskiego kontekstu Zagłady używane było zazwyczaj w dwóch znaczeniach. Jako ekwiwalent słowa bystander, a więc na oznaczenie trzeciego ogniwa triady Hilberga. Mieliśmy tu do czynienia z postronnym, któremu blisko do widza czy gapia. Słowo to używane było także jako ekwiwalent słowa witness w sensie wywodzącym się od Izajasza, a dookreślonym przez Primo Leviego ${ }^{4}$. O polskiej większości zwykło się mówić jako o świadkach Zagłady w rozumieniu Hilbergowskim lub - w rozumieniu Leviego - jako o świadkach świadków Zagłady, czyli świadkach ofiar5.

3 Por. M.C. Steinlauf Pamięć nieprzyswojona. Polska pamięć Zagłady, przeł. A. Tomaszewska, Cyklady, Warszawa 2001 - wydanie amerykańskie 1997.

4 „Powtarzam to raz jeszcze: to nie my, którzy przeżyliśmy, jesteśmy prawdziwymi świadkami. [...] My, którzy przeżyliśmy, stanowimy odbiegającą od normy mniejszość, a nie tylko nieliczną garstkę ocalałych [...]. Kto zszedł na dno, kto nie uniknął wzroku Meduzy, ten nie powrócił, by dać świadectwo, albo powrócił niemy. [...] Oni stanowią regułę - my zaś wyjątek. [...] My mówimy zamiast nich, mówimy w ich imieniu" (P. Levi Pogrążeni i ocaleni, przeł. S. Kasprzysiak, Wydawnictwo Literackie, Kraków 2007, s. 100-101). W tym sensie ocalali stają się świadkami świadków. W perspektywie posttraumatycznej natomiast „świadków Zagłady nie ma wcale, ponieważ tego rodzaju traumatyczne zdarzenie jest oparte na utracie doświadczenia, zostawia po sobie niemożność sprostania rzeczywistości poprzez akt złożenia świadectwa" (G. Niziołek Polski teatr Zagłady, Instytut Teatralny im. Zbigniewa Raszewskiego \& Krytyka Polityczna, Warszawa 2013, s. 49 - w nawiązaniu do tekstu: D. Laub Zdarzenie bez świadka: prawda, świadectwo oraz ocalenie, przeł. T. Łysak , "Teksty Drugie” 2007 nr 5, s. 118-130). W polskim kontekście refleksja ta nie znajduje zastosowania, gdyż ofiary - nie wszystkie, lecz jednak masowo - wypowiadały swoje doświadczenie, niewyrażalność zaś była niejednokrotnie zewnętrzną i kulturowo konstruowaną formą represji lub wręcz blokowania świadectwa.

5 Przypadkiem domagającym się osobnej polemiki jest kategoria świadków świadectw zastosowana do prozy języka polskiego autorów niewspółczesnych Zagładzie (por. A. Mach Świadkowie świadectw. Postpamięć Zagłady w polskiej literaturze najnowszej, Fundacja na Rzecz Nauki Polskiej, Warszawa-Toruń 2016). 
Badacze tekstów kultury, którzy wychodzili z założenia, że grupa dominująca była grupą świadków, w punkcie dojścia opisali fiasko polskiego świadectwa i polskiego paradygmatu świadectwa ${ }^{6}$. Pośrednio zatem - choć nie formułowali tego w ten sposób - podważyli kategorię polskiego świadka Zagłady.

Dotychczasowe kategorie opisu Zagłady okazały się nieadekwatne także wobec rozumianej neopozytywistycznie wiedzy o stanie faktycznym - nie tylko w rezultacie gwałtownego przyrostu owej wiedzy. W świetle relektury wcześniejszego i, zdawałoby się, oswojonego oraz przyswojonego korpusu analitycznego wyszło bowiem na jaw, że to owe narzędzia terminologiczne - nie zaś cenzura czy nie niepełny dostęp do źródeł - pozwalały latami nie dostrzegać lokalnego kontekstu Zagłady. Zasłaniały go i pozwalały pomijać, jeśli nie zakłamywać. Tworzyły warunki odbioru, które nie pozwalały słyszeć - czy może pozwalały nie słyszeć - głosu ofiar, a niekiedy także utrudniały, jeśli nie udaremniały ofiarom przebywającym w polskim kręgu kulturowym artykulację ich doświadczenia ${ }^{7}$. Jakim terminem można zatem zastąpić kategorię polskiego świadka Zagłady?

\section{Kilka faktów, co nienowe}

Stawka operacji terminologicznej jest najzupełniej kluczowa, jeśli zważyć, że tłem polskiego szoku narracyjnego była rewizja definicji Zagłady odnosząca się do całej okupowanej Europy. Jej istotę stanowiło rozszerzenie pola widzenia o współzależność między niemieckim nazistowskim przedsięwzięciem eksterminacyjnym a jego lokalnymi kontekstami. Pytanie o to, na ile całkowita była eksterminacja Żydów w różnych krajach, odsyła bowiem właśnie do owych lokalnych kontekstów. W skali okupowanej Polski chodzi o prawie 100\% Żydów, którzy znajdowali się na jej terytorium. Wojnę w okupowanej Polsce przeżyło od 30 tysięcy do 50 tysięcy Żydów - głównie w obozach pracy, obozach koncentracyjnych, oddziałach partyzanckich w lasach na terenach, gdzie funkcjonowała partyzantka radziecka. Tych, którzy przeżyli z pomocą czy dzięki pomocy nieżydowskiego otoczenia, była śladowa mniejszość. (Liczba Sprawiedliwych wśród Narodów Świata z Polski - udokumentowana

6 Por. G. Niziołek Polski teatr Zagłady; L. i F. Tych Świadkowie Shoah. Zagłada Żydów w polskich pamiętnikach i wspomnieniach, w: F. Tych Długi cieńZagłady. Szkice historyczne, Żydowski Instytut Historyczny IN-B, Warszawa 1999, s. 9-54.

7 Charakterystyczne pod tym względem są różnice między wypowiedziami formułowanymi po polsku i np. w jidysz przez te same osoby (casus np. Szymona Datnera). 
w Yad Vashem na 6,5 tysiąca - to mniej niż $1 / 4$ procenta nieżydowskiej populacji). Stanowi to o randze pytania o miejsce i rolę nieżydowskiej większości i kultury dominującej w strukturze zbrodni.

Periodyzacja zagłady Żydów polskich (w tym osób przyporządkowanych do tej kategorii wbrew samookreśleniu) obejmuje trzy fazy: gettoizację, eksterminację (na którą składa się eksterminacja masowa w ramach Einsatz Reinhardt oraz poprzedzająca ją eksterminacja masowa metodami tradycyjnymi - franc. Shoah par balles) i polowanie na Żydów (niem. Judenjagd). Niemieckie sprawstwo we wszystkich trzech fazach nie ulega wątpliwości i nie podlega dyskusji. Polska - reprezentowana przez rząd na wychodźstwie - była członkinią koalicji antyhitlerowskiej i nie miała kolaboracyjnego rządu. Udokumentowana jest natomiast szeroko zakrojona kolaboracja lokalnej policji (dawniej - a raczej bardzo niedawno - polskiej policji państwowej) oraz władz niższego szczebla, czyli lokalnej administracji w jej kształcie zazwyczaj przedwojennym. Szczególnie aktywne w procesie Zagłady były także służby mundurowe w rodzaju ochotniczej straży pożarnej czy hufców pracy. Miejsce i rola tych instytucji sytuuje je po stronie sprawców - także w sensie możliwym do odniesienia do ich poszczególnych członków na gruncie prawa karnego. Osobną sprawą jest postawa i polityka rządu w Londynie ${ }^{8}$ i polskiego państwa podziemnego (Delegatury Rządu na Kraj i Armii Krajowej)9 - postawa i polityka, których co do reguły nie daje się ocenić pozytywnie. Nie to jednak jest przedmiotem niniejszej analizy.

Miejsce i rola polskich instytucji postrzegane są zazwyczaj jako drugorzędne. Miejsce i rola większościowej populacji chrześcijańskiej - jako trzeciorzędne. W obrazie wydarzeń przypada im wszystkim miejsce na tzw. obrzeżach Zagłady. I na tychże obrzeżach liczba żydowskich ofiar nieżydowskiej większości - czy to ujętej, czy nieujętej w ramy instytucji - szacowana jest na około 125 tysięcy. Względnie dwa razy tyle, jeśli wziąć pod uwagę liczbę Żydów, którym udało się uniknąć wywózki i którzy zostali zamordowani zaraz

8 Por. D. Engel In the Shadow of Auschwitz: The Polish Government-in-exile and the Jews, 1939-1942, University of North Carolina Press, Chapel Hill 1987; D. Engel Facing a Holocaust: The Polish Government-in-exile and the Jews, 1943-1945, University of North Carolina Press, Chapel Hill 1993.

9 Por. D. Libionka ZWZ-AK i Delegatura Rządu RP wobec eksterminacji Żydów polskich, w: Polacy i Żydzi pod okupacją niemieckq 1939-1945. Studia i materiały, red. A. Żbikowski, IPN - Komisja Ścigania Zbrodni przeciwko Narodowi Polskiemu, Warszawa 2006, s. 15-207; A. Puławski W obliczu Zagłady. Rzq̨d RP na uchodźstwie, Delegatura Rzq̨du RP na Kraj, ZWZ-AK wobec deportacji Żydów do obozów zagłady (1941-1942), IPN, Lublin 2009. 
po tym, jak niemieckie - i inne - jednostki likwidacyjne opuściły miasta i miasteczka.

\section{Obrzeża czy rama Zagłady?}

Zacząć należy od tego, że kategoria bystanders - jakkolwiek by ją tłumaczyć na język polski - zakłada brak kontaktu między Żydami a nie-Żydami, jakoby całkowicie odizolowanymi od siebie na mocy niemieckich zarządzeń i działań. Znakiem emblematycznym dla tego wyobrażenia jest drewniany most nad warszawską ulicą Chłodną, czyli „korytarzem aryjskim”, pilnie strzeżonym i odgrodzonym od getta wysokim murem. Tymczasem kontakt między Żydami a nie-Żydami istniał nieprzerwanie we wszystkich trzech fazach Zagłady - także w Warszawie i także przy Chłodnej, ledwie czterysta metrów dalej. Natomiast większość z sześciuset gett ustanowionych przez Niemców w okupowanej Polsce była gettami ogrodzonymi prowizorycznie lub całkiem otwartymi. W każdym z nich panowały warunki bliskie katastrofie humanitarnej lub identyczne z katastrofą humanitarną.

Zachowanie Żydów często bywa opisywane jako niezrozumiałe. Niekiedy nawet badacze pytają: dlaczego poszli do getta, dlaczego nie uciekli z getta itd. Najprostsza odpowiedź na te pytania zawiera się w losach tych, którzy usiłowali nie pójść do getta i tych, którzy z getta uciekali. Israel Gutman, urodzony w Warszawie, ocalały, a do tego historyk, zwykł natomiast odpowiadać serią pytań:

Dokąd uciekać? Oni sobie nie wyobrażają tego... Nawet w dżungli można uciekać... może się to skończyć bardzo źle, ale jest jakaś droga, możliwość poruszania się, wyjścia z tej klatki. A getto to była klatka bez wyjścia - dokąd? Do kogo? [...] Dokoła tego muru był inny mur... Polacy nie powinni brać odpowiedzialności ogólnonarodowej za to, co było, ale w pewnym sensie - tak. ${ }^{10}$

Z getta uciekano w ostateczności, najczęściej do innego getta. Niejednokrotnie także wracano do getta ze strony aryjskiej. (Zaś sam Israel Gutman uciekł: z transportu do Treblinki z powrotem do getta warszawskiego, gdzie wziął udział w żydowskim powstaniu. I ocalał. W Mauthausen, dokąd trafił

10 Z profesorem Israelem Gutmanem rozmawia Barbara Engelking, "Zagłada Żydów” 2013 nr 9, s. 226. 
przez Majdanek i Auschwitz). Co dokładnie oznacza konkluzja wypowiedzi Gutmana - owo „nie, ale tak”, „nie powinni, ale powinni” Polacy wziąć ogólnonarodową odpowiedzialność za to, co się stało?

W ciągu całego okresu niemieckiej okupacji Żydzi odbierali werbalne i niewerbalne sygnały emitowane przez chrześcijan. Sygnały te lokowały się na przedłużeniu i pozostawały w zgodzie z większościowymi postawami i zachowaniami względem Żydów przed wojną. Składały się one na cykliczną przemoc na tle religijnym (Wielki Piątek, Boże Ciało, Wniebowzięcie Najświętszej Maryi Panny 15 sierpnia), apartheid, czyli segregację rasową oddolną (chodniki chrześcijańskie) i odgórną (Jabłonna 1920, getto ławkowe 1937-1939), dyskryminację ekonomiczną oddolną (bojkot ekonomiczny) i odgórną (reformy Grabskiego 1924), fale pogromów (1918-1919, 1920, 1935-1937), obóz internowania w Zbąszyniu (1938), aryzację państwowego szkolnictwa i harcerstwa oraz innych państwowych instytucji (przykład: Polskie Radio), powszechność podżegania do nienawiści i wszechobecność mowy nienawiści, eliminacyjne programy i eksterminacyjne fantazmaty obecne w języku oraz ikonosferze. Po niemieckiej napaści na Polskę - przed ustanowieniem gett - panowała „atmosfera pogromowa” (to słowa Emanuela Ringelbluma) z nagminnym biciem Żydów w biały dzień i jawnymi kradzieżami w sklepach należących do Żydów. W samej tylko Warszawie owa atmosfera kulminowała w trwającym tydzień pogromie na Wielkanoc 1940 roku. Po ustanowieniu w Warszawie getta 12 tysięcy ludzi zostało siłą wpędzonych za druty przez polską policję granatową na podstawie imiennych denuncjacji. Wszystko w roku 1940.

Faza gettoizacji to także - niezależnie od niemieckiego rabunku - przejmowanie własności Żydów przez Polaków11. Proces ten przyjmował różne formy, lecz wszystkie one przebiegały na zasadach rabunkowych: były zbliżone do rabunku lub tożsame z rabunkiem - jak np. tzw. handel między gettem a tzw. stroną aryjską. Druga faza Zagłady oznaczała dalszą „aryzację" żydowskiej własności, włączając $w$ to rabowanie uciekinierów z gett i transportów. Wszystkie te działania - nawet jeśli nie towarzyszyły im denuncjacje - pozbawiały ofiary wszelkiej szansy na przeżycie. Warunkiem korzystania z polskiego biznesu pomocy było wszak posiadanie ponadprzeciętnych

11 Por. Klucze i kasa. O mieniu żydowskim w Polsce pod okupacją niemieckq i we wczesnych latach powojennych 1939-1950, red. J. Grabowski, D. Libionka, Stowarzyszenie Centrum Badań nad Zagładą Żydów, Warszawa 2014. 
środków materialnych ${ }^{12}$. Obowiązywał bowiem podwójny cennik towarów i usług. Toczący się wówczas proces można określić jako rozbieranie Żydów do śmierci.

Postawy i zachowania chrześcijańskiej większości były jednym z czynników, który w znacznym i znaczącym stopniu determinował sytuację Żydów - w tym liczbę żydowskich ofiar - nie tylko w trakcie ostatniej fazy Zagłady, lecz także w okresie gettoizacji i masowej eksterminacji. Rola nieżydowskiej większości - sytuowana dotychczas w okresie po 1942 roku i w obszarze zwanym obrzeżami Zagłady - powinna być zatem datowana i rozpatrywana od samego początku niemieckiej okupacji. Powinna być również opisywana w kontinuum z dyskursem i praktykami antysemickimi istniejącymi w II Rzeczypospolitej. Z powyższych powodów kategoria obrzeży Zagłady jest moim zdaniem nieadekwatna w odniesieniu do polskiego kontekstu Zagłady. Uważam, że mamy tutaj do czynienia nie z obrzeżami, lecz ze społeczno-kulturową ramą konfigurującą pole, w którym rozegrała się Zagłada jako niemiecka nazistowska zbrodnia na Żydach.

\section{Obserwacja jako uczestnictwo. Parametry spojrzenia}

W ciągu całego czasu trwania Zagłady nieżydowska większość przedsiębrała szereg działań - tyleż cząstkowych i rozproszonych, co szeroko rozpowszechnionych. Owe działania były nieporównanie częstsze niż denuncjacje i bezpośrednie mordowanie Żydów. Jako mniej wymierne są one znacznie słabiej opisane w historiografii Zagłady. Najbardziej wspólnym i permanentnym z owych działań - nieuznawanym nawet za działanie sensu stricto - była zaś tzw. bierna obecność nieżydowskich obserwatorów, np. tworzących szpalery podczas wywózek czy praktykujących społeczny rytuał rozpoznawania Żyda wobec tych, którzy usiłowali przeżyć po tzw. aryjskiej stronie. Przy bliższej analizie staje się jasne, że sama obecność tzw. biernych obserwatorów była najbardziej podstawową formą sprawczości (agency) czy wręcz sprawstwa. Ten czynnik miał bowiem decydujący wpływ na los wielu ofiar, które za jego sprawą zostały pozbawione możliwości ucieczki czy ukrycia się, czy pozostania w ukryciu.

To dlatego kategoria świadka nie pozwala na precyzyjny opis miejsca i roli polskiej większości dominującej względem żydowskiej mniejszości.

12 J. Grabowski Ratowanie Żydów za pieniq̨dze - przemysł pomocy, "Zagłada Żydów” 2008 nr 4, s. 81-110. 
Jako taka powinna zostać wykreślona ze słownika opisu polskiego kontekstu Zagłady wraz z towarzyszącym jej polem kategorialnym (bezsilność, wina niezarzucalna, bierność, obojętność, trauma). Jednocześnie zaś objęcie postaw i zachowań większości przy pomocy jednej kategorii jest warunkiem utrzymania triady. Chodzi o to, by nie dzielić zjawiska na tak wiele części, że przestaniemy je postrzegać jako jedno zjawisko i wyodrębniać jako wyraźny problem. Uważam, że nieżydowską większość w polskim kontekście należy opisać jako obserwatorów uczestniczących.

Kategoria obserwacji uczestniczącej (obserwacji jako uczestnictwa) byłaby nieredukowalną częścią wspólną szerszej typologii zachowań. Termin ten pozwala, jeśli to konieczne, na uszczegółowienie rozmaitych dalszych trybów uczestnictwa. Wydaje się odpowiednio wydajny i elastyczny, by pozwolić na uchwycenie zróżnicowanych form zjawiska, włączając w to jego ewolucję w czasie. Pozwala także wziąć pod uwagę, że ci sami ludzie podejmowali różne działania w różnych miejscach w różnym czasie. I to, że wielu z nich działało przez zaniechanie.

Jednego możemy być pewni: patrzyli wszyscy. Wszelako to nie sam fakt patrzenia, lecz sposób patrzenia miał decydujący wpływ na los ofiar. To ów sposób stanowił „mur wokół muru” i sprawiał, że - jak wyraził się Jan Karski - „cała Polska była gettem”13: śmiertelną pułapką bez wyjścia, bez zewnętrza. Spojrzenie jest tym, co Bourdieu określił jako habitus: wcieleniem i egzekwowaniem norm kulturowych, czyli porządku społecznego. W tym wypadku był to porządek, który nie przewidywał nie tylko bezpiecznego miejsca, lecz w ogóle żadnego miejsca nie przewidywał dla Żydów. Był on bowiem systemem opartym na etniczno-religijnej definicji wspólnoty. I nie było dla niego alternatywy prawomocnej w sensie społeczno-kulturowym. Modele alternatywne - takie jak wspólnota ufundowana na obywatelstwie - były (i są do dzisiaj) postrzegane w Polsce przeważnie jako zewnętrzne, obce, a wręcz zagrażające.

Większość dominująca zatem - włączając w to jej elity w społecznym rozumieniu tego słowa - nie definiowała Żydów jako współobywateli bądź po prostu ludzi w krańcowej potrzebie, lecz utożsamiała ich z wyobrażonym przez siebie wizerunkiem Żyda: sprowadzającym wielość do jedności, różnicę do tożsamości. W etniczno-religijnym (polskim katolickim) rozumieniu narodu ów fantazmatyczny Żyd jest wrogiem konstytutywnym fantazmatyczną figurą, w opozycji do której skonstruowana została tożsamość większości:

13 J. Karski Widziałem, oprac. M. Cichy, "Gazeta Wyborcza”, 2-3 października 1999, s. 15. 
najpierw religijna, następnie narodowa. Jest to tożsamość zdeterminowana przez opowieści takie jak narracja o Ukrzyżowaniu czy mit żydokomuny. (Ukrzyżowanie i żydokomuna to dwa warianty jednego i tego samego wzoru. Czy może raczej mit żydokomuny - jak mit mordu rytualnego - powtarza strukturę opowieści o Ukrzyżowaniu). Te właśnie narracje pozwoliły większości zracjonalizować niemiecką politykę. Ale przede wszystkim i nade wszystko czyniły tę politykę możliwą do pojęcia, ponieważ w perspektywie antysemityzmu jako zjawiska długiego trwania Żyd był postrzegany jako szkodliwy element, który należy usunąć.

Przemoc wobec Żydów nie była przemocą anomiczną. Była to przemoc zakorzeniona w normach i wartościach. Instytucjonalna i nieinstytucjonalna kolaboracja z Niemcami w zakresie zagłady Żydów nie odbywała się w społecznej, kulturowej i moralnej próżni. Za prawodawcę w zakresie moralności uważane było polskie państwo podziemne (w obu jego pionach: cywilnym i wojskowym) - twór stanowiący pierwsze ucieleśnienie ideału Polski dla Polaków ${ }^{14}$. Emanacją owego ideału był dyskurs i praktyki składające się na politykę podziemnego państwowego organizmu wobec Żydów: $\mathrm{w}$ roku $1940^{15}$, w roku $1941^{16}$, w roku $1942^{17}$, następnie zaś w roku $1943^{18} \mathrm{i}$ do końca istnienia podziemnych struktur państwowych. Wymownym tego przykładem jest historia stosunku Londynu i Delegatury Rządu na Kraj do Rady Pomocy Żydom „Żegota"19.

Wszelako najbardziej widocznym punktem w krajobrazie Zagłady - punktem, który dominował nad krajobrazem Zagłady w dosłownym sensie, lecz

Por. M.C. Steinlauf Pamięć nieprzyswojona, s. 59.

Por. J. Karski Zagadnienie żydowskie w Polsce pod okupacjami, "Mówią Wieki” 1992, nr 4, s. 3-8; J.T. Gross Raport Jana Karskiego o stosunkach polsko-żydowskich w czasie wojny, "Mówią Wieki" 1992, nr 4, s. 2. Chodzi o raport Jana Karskiego z początków roku 1940, sfałszowany - przez Karskiego - według wskazań rządu polskiego na wychodźstwie z siedzibą w Angers.

Por. WokółJedwabnego, red. P. Machcewicz, K. Persak, IPN - Komisja Ścigania Zbrodni przeciwko Narodowi Polskiemu, Warszawa 2002, t. 1 i 2.

Por. W. Rappak Raport Karskiego - kontrowersje i interpretacje „ZZagłada Żydów” 2014, t. 1, s. 96-130.

Por. Wojna żydowsko-niemiecka. Polska prasa konspiracyjna 1943-1944 o powstaniu w getcie Warszawy, wyb. i oprac. P. Szapiro, Aneks, Londyn 1992; D. Libionka Walka i propaganda. Powstanie w getcie warszawskim z perspektywy polskiego Londynu, "Zagłada Żydów” 2014, t. 1, nr 10, s. 57-95.

9 Por. M. Urynowicz La Délégation du Gouvernement de la République Polonaise de Londres et le financement du Conseil d'aide aux Juifs (Zegota), w: Juifs et Polonais 1939-2008, red. J.-C. Szurek, A. Wieviorka, Albin Michel, Paris 2009, s. 79-93. 
w opisie wydarzeń pozostaje nieobecny - był Kościół katolicki: źródło norm moralnych, strażnik indywidualnej i zbiorowej tożsamości w jej etniczno-religijnym (polskim katolickim) rozumieniu. Wiemy, że do kaźni Żydów z rąk chrześcijańskich sąsiadów dochodziło w biały dzień, na widoku publicznym, najczęściej właśnie w bezpośrednim sąsiedztwie kościoła. Wiemy, że przez cały okres hitlerowskiej okupacji chrześcijanie zbierali się w kościele co najmniej w każdą niedzielę, uczestniczyli w obchodach świąt religijnych, chodzili do spowiedzi. Mamy również dowody na to, że przy religijnych okazjach rozpoznawali na sobie nawzajem ubrania zamordowanych żydowskich sąsiadów. Niedostępność kościelnych archiwów sama w sobie stanowi informację. Nie powinna też być przeszkodą w formułowaniu hipotez. Z krzyżowej analizy źródeł niekościelnych wynika dostatecznie wiele. Nasza wiedza jest wystarczająca, żeby pytać - o religijną prawomocność i kościelną legitymizację tego, co działo się z Żydami.

Przez odwołanie do kategorii antysemityzmu jako kodu kultury, opisanej przez Shulamit Volkov ${ }^{20}$, możemy mówić o polskiej kulturze większościowej jako kulturze strukturalnie antysemickiej. Lokalny kontekst Zagłady w Polsce był zdominowany przez antysemityzm jako zjawisko długiego trwania: jako wzór kultury - zespół wyobrażeń i dyskursów, tekstów kultury i praktyk społecznych. Jako taki antysemityzm nie tylko powodował przemoci i wykluczenie, lecz także pozwalał na ich integrację w obrębie wyobrażeń o porządku świata. Tym samym zaś delegitymizował współczucie dla ofiar czy też narzucał mu ramy, które sprawiały, że owo współczucie pozostawało bez trwałych pozytywnych dla ofiar konsekwencji. Współczucie dla ofiar było postrzegane jako zagrożenie dla wspólnoty i jej spójności. Empatia lokowała się w obszarze społeczno-kulturowej nieprawomocności. I to właśnie przesądzało o ryzyku związanym z pomocą Żydom, nie zaś kara śmierci. W myśl niemieckiego prawodawstwa obowiązującego w okupowanej Polsce kara śmierci groziła za niezliczone inne działania, które mimo to podejmowano powszechnie i niekiedy całkiem otwarcie (niekolczykowanie zwierząt hodowlanych i ich ubój, posiadanie radia, produkcję alkoholu czy konspirację). Największym niebezpieczeństwem dla pomagających Żydom było dostrzeżenie przez czujne oko nieżydowskiej większości.

20 S. Volkov Antysemityzm jako kod kulturowy, w: Ze sobq, oboksiebie, przeciwko sobie. Polacy, Żydzi, Austriacy i Niemcy wXIX i na początku XX wieku, red. B. Breysach, przeł. B. Hański, Znak, Kraków 1995, s. 7-41. 


\section{Obserwacja jako uczestnictwo. Tryby i funkcje}

Czujne oko nieżydowskiej większości było czymś w rodzaju gospodarskiego oka i sprawowało władzę, którą można nazwać władzą spojrzenia (franc. le droit de regard), prawem kontroli czy superwizji. Za sprawą tego mechanizmu getto nie potrzebowało murów. Natomiast tam, gdzie mury istniały - jak w Warszawie - nie musiały być hermetyczne, ponieważ getto obowiązywało również po „aryjskiej” stronie. Getto było performatywem niezależnym od formalnych wyznaczników i terytorialnych delimitacji. Prawo spojrzenia zasadzało się na prawie do produkcji Żyda. Obserwator uczestniczący przywoływał dostrzeżonego/dostrzeżoną do żydostwa, jak przywołuje się do porządku. Wkraczamy tutaj w sferę ubezwłasnowolnienia: pozbawienia prawa do samostanowienia.

Produkcja Żyda - zwana rozpoznawaniem - polegała na nakładaniu na jednostkę fantazmatu Żyda. Obiekt spojrzenia był wyposażany w ten sposób nie tylko w zestaw cech, ale też w instrukcję obsługi. W porządku symbolicznym już "przednowoczesny antysemityzm, religijny, etniczny i społeczny w narracji symbolicznej wyznaczał im [Żydom - przyp. E.J.] prawdziwe «miejsce niebezpieczne», które w każdej chwili mogło zniknąć z powierzchni ziemi" ${ }^{21}$. Scenariusz akcji był zatem wstępnie przygotowany - podszykowany - i przynależał do obszaru społeczno-kulturowej oczywistości charakterystycznej dla dominującej percepcji: zarówno na poziomie mentalności, jak i wrażliwości. Ów społeczny scenariusz to wzór kultury właśnie. Wzory kultury zaś - nieuświadomione i niepoddane krytyce - działają z siłą przymusu.

Według Michela Foucaulta „widzialność jest pułapką"22. Formuła Jana Karskiego - „Cała Polska była gettem" - może zostać przetłumaczona na obraz okupowanej Polski jako rzeczywistości panoptycznej. Rzeczywistość panoptyczna to społeczno-kulturowy aparat umożliwiający akt permanentnego wiedzenia i natychmiastowej identyfikacji oraz gwarantujący, że najmniejszy i najbardziej peryferyjny element nie zostanie pominięty. A zatem aparat sięgający wszędzie i dosięgający wszystko. Foucault określał go jako kompletny „aparat wszechdyscyplinarny”. Jako coś, co „nie ma zewnętrza ani luk, [co] nie ustaje, póki całkowicie nie wypełni swojego zadania"23. Ten aparat pracuje zresztą w Polsce do dzisiaj. Można go zatem badać w działaniu na bieżąco.

21 J. Tokarska-Bakir Żydzi u Kolberga, w: tejże Rzeczy mgliste. Eseje i studia, Pogranicze, Sejny 2004, s. 49-72.

M. Foucault Nadzorować i karać. Narodziny więzienia, przeł. T. Komendant, Aletheia, Warszawa 2009, S. 195.

Tamże, s. 228. 
Rzeczywistość panoptyczna jest „ogromną i mikroskopijną zarazem maszynerią" ${ }^{24}$, „bezgranicznie zwartym splotem procedur panoptycznych"25. W wersji polskiej - z perspektywy ofiar Zagłady - ta struktura była ufundowana na wszechobecnym i wszechwidzącym chrześcijańskim obserwatorze, stanowiącym rozproszone spojrzenie o wielu twarzach, „które przekształca całość ciała społecznego w pole percepcji: tysiące rozmieszczonych wszędzie oczu, ruchliwe i gotowe na zawołanie punkty obserwacyjne"26. Pisząc o rojeniu się czy mrowieniu mechanizmów dyscyplinarnych, Foucault używał terminu „dezinstytucjonalizacja”. W polskim kontekście mamy do czynienia z formą - czy raczej mechanizmem lub strukturą - już wyjściowo zdezinstytucjonalizowaną: nieformalną, nieinstytucjonalną.

W tym miejscu pojawia się problem z kategorią głównych sprawców przyporządkowaną w opisie wydarzeń Niemcom. Z punktu widzenia ofiar bowiem po roku 1942 rola widzącego otoczenia okazała się kluczowa, a konkretnie rozstrzygająca. Widzące otoczenie stało się głównym rozgrywającym: „zamawiającym ostatnią posługę u Niemców” czy wręcz „zlecającym ją Niemcom" - według oryginalnego sformułowania Tadeusza Markiela ze wsi Gniewczyna ${ }^{27}$. Odnosząc się do struktury mordów charakterystycznych dla tego okresu, Andrzej Żbikowski kwalifikuje Niemców mordujących Żydów na podstawie denuncjacji jako „pośredników” zbrodni ${ }^{28}$. Chrześcijanie byli świadomi możliwości powołania się na alibi w postaci Niemców jako głównych sprawców czy też - jak wyraził się Calel Perechodnik - Niemców jako „redaktora naczelnego”: „Niemcy, w razie czego i tak wszystko pójdzie na karb Niemców"29. I faktycznie - jest to odkrycie Aliny Skibińskiej - w powojennym Rejestrze miejsc i faktów dotyczących zbrodni popetnionych przez hitlerowskiego okupanta po społecznej praktyce polowania na Żydów pozostały zapisy w rodzaju: „W tym i w tym miejscu, w takim a takim czasie, Niemcy

24

Tamże, s. 216.

Tamże, s. 217.

Tamże, s. 208.

T. Markiel Gniewczyna w czas wojny, w: T. Markiel, A. Skibińska „Jakie ma to znaczenie, czy zrobili to z chciwości?". Zagłada domu Trynczerów, Stowarzyszenie Centrum Badań nad Zagładą Żydów, Warszawa 2011, s. 88.

8 A. Żbikowski U genezy Jedwabnego. Żydzi na Kresach Północno-Wschodnich II Rzeczypospolitej. Wrzesień 1939-lipiec 1941, Żydowski Instytut Historyczny, Warszawa 2006, s. 229.

C. Perechodnik Spowiedź. Dzieje rodziny żydowskiej podczas okupacji hitlerowskiej w Polsce, oprac. i posł. D. Engel, Ośrodek KARTA, Warszawa 2004, s. 124. 
z takiej czy innej formacji zamordowali tylu a tylu Żydów"30. W tym świetle niezrozumiałe są sceny w rodzaju tej, która rozegrała się w Węgrowie podczas likwidacji getta - przez Niemców - w roku 1942. „Mężczyzna stojący obok małej dziewczynki krzyczał do Polaków: «Wpychacie nas do pieców»"31. Dominująca polska (przeciw)narracja o Zagładzie zatrzymała w pamięci jedynie ostatnie ogniwo procesu.

Fakt śmierci Żydów z rąk konkretnego, zazwyczaj niemieckiego mordercy czy widoczne znaki - jak mury getta lub komory gazowe - nie odzwierciedlają istoty procesu, który toczył się w społecznej tkance okupowanej Polski. Proces ten nazwałabym working toward the Holocaust, zainspirowana sformułowaniem Iana Kershawa: working toward the Führer. Raz jeszcze: working toward the Holocaust. Żadną miarą working toward the Führer czy working toward the Germans. Ani bezpośredni polscy sprawcy, ani wspólnoty, z których pochodzili i wśród których działali - wspólnoty obserwatorów uczestniczących, które po wojnie podjęły ich stanowczą obronę na salach sądowych - nie zakwalifikowaliby swoich czynów jako kolaboracji z Niemcami, a tym bardziej III Rzeszą czy hitleryzmem. Mieli oni względem Żydów swoje własne cele i priorytety wynikające z imperatywu samoobrony. Zbieżność owego imperatywu z niemieckim nazistowskim antysemityzmem i z niemieckim nazistowskim przedsięwzięciem eksterminacyjnym nie była okolicznością kompromitującą ów imperatyw. Wręcz przeciwnie, była postrzegana jako okazja, szansa. W Polsce bowiem - w odróżnieniu od np. Francji - antysemityzm nie pozostawał w sprzeczności z etosem antyhitlerowskiego ruchu oporu i szerzej, etosem patriotycznym.

Fragmentaryczne i rozproszone gesty - jak i całe sekwencje zachowań - powinny zostać dostrzeżone jako system charakteryzujący się zarówno czytelną regułą, jak i elastycznością, zdolnością adaptacji w konkretnych sytuacjach. Jeśli opisujemy Zagładę jako niemiecki nazistowski system totalnej eksterminacji Żydów, należy stwierdzić, że polska większość dominująca uszczelniła jego niedoskonałości, rozstrzygając w ten sposób o stopniu jego wydajności. Z punktu widzenia analizy funkcjonalnej obserwator uczestniczący sprawował nieformalną, lecz faktyczną kontrolę społeczną nad

A. Skibińska Gniewczyna w czas wojny - zbliżenie, w: T. Markiel, A. Skibińska „Jakie ma to znaczenie, czy zrobili to z chciwości?"..., s. 250. hamer, red. i wstęp J. Grabowski, Stowarzyszenie Centrum Badań nad Zagładą Żydów, Warszawa 2015 , s. 130. 
ostatecznym charakterem Ostatecznego Rozwiązania. W Polsce ta kontrola nie ustała wraz z wojną. Dlatego w odniesieniu do ostatniej fazy Zagłady, a także okresu powojennego, można przywołać figurę kłosiarzy, którzy wkraczają do akcji po głównych żniwach i zbierają to, co zostało po przejściu żniwiarzy właściwych. Mimo klasowej - wiejskiej, chłopskiej - konotacji obraz ten stosowałby się do całego przekroju społecznego. Pozwalałby również uwzględnić często brakujący element obrazu: aktywność dzieci.

Zapytany o „stronę aryjską”, Israel Gutman odpowiedział:

Ci, którzy wychodzili z placówkami, chodzili w kolumnach. Jak wracali, zawsze było to samo: dzieci krzyczały, naśmiewano się z nich. Czy to wszystko był antysemityzm? Przecież to śmieszne. Ale oni tak to odczuwali, że jak wychodzą - ludzie tak się patrzą. ${ }^{32}$

„Przecież to śmieszne”. I to jest właśnie to - owo das - rozproszone i nieskoordynowane, a jednocześnie tak całkowite, nieustające, wszechogarniające, nieubłagane i nieomylne. Permanentne i performatywne. Tymi, którzy zdeterminowali poziom wydajności niemieckiego nazistowskiego przedsięwzięcia eksterminacyjnego w okupowanej Polsce, byli obserwatorzy uczestniczący.

\section{Terminologia i narracje - stawka}

W procesie negocjowania „pułapu prawdy"33, jaki polska kultura dominująca prowadziła i prowadzi z własnym odbiciem w oczach tzw. zagranicy, narracja o polskim świadku Zagłady stanowiła alternatywę dla narracji o Sprawiedliwych rozumianej jako narracja o powszechności pomocy Żydom w okupowanej Polsce. Narracja o Sprawiedliwych została bowiem skompromitowana - zdawało się, ostatecznie - w roku 1968. Obie narracje jednakże były narcystyczne, wymierzone w wiedzę o stanie faktycznym i zwrócone przeciwko ofiarom - narracja o Sprawiedliwych na zasadzie active agression, narracja o polskim świadku na zasadzie passive agression. Obie - jako sposoby unikania konfrontacji z Zagładą i antysemityzmem - stanowiły część problemu, który usiłowały wymijać.

Z profesorem Israelem Gutmanem rozmawia Barbara Engelking, s. 227. 
W roku 2000 w centrum uwagi znalazło się to, co spychane dotąd poza nawias refleksji, usuwane z pola widoczności, uważane za ekstremum i przesadę, a więc bezpiecznie odsunięte od wyłączonego środka (nieżydowskiej większości i polskiej kultury dominującej). Innymi słowy, do publicznej debaty przedostała się wiedza rzeczowa o polskim kontekście Zagłady, nieodłączna od pytania o jej wcześniejsze cenzurowanie, reglamentowanie i neutralizowanie zarówno przed rokiem 1989, jak i potem - we wszystkich obiegach polskiej kultury.

W ramach narracyjnej rewolucji humanistyka i nauki społeczne zaczęły badać i problematyzować lokalne kontinuum antysemickiej przemocy i wykluczenia oraz źródła owego wykluczenia i owej przemocy ulokowane w głównym nurcie kultury ${ }^{34}$. Zaczęto dokumentować i dekonstruować społeczno-kulturową prawomocność antysemityzmu ${ }^{35}$. Pozwalając nie dostrzec/ nie pozwalając dostrzec miejsca nieżydowskiej większości w strukturze zbrodni, kategoria polskiego świadka Zagłady stanowiła bowiem - i chroniła jednocześnie - większościową narrację. Tym samym zaś obsługiwała interesy grupy większościowej - materialne i symboliczne. Te ostatnie w ich wymiarze przede wszystkim tożsamościowym.

Od początku debaty jedwabieńskiej było jasne, że jej stawką nie jest wycinkowa korekta obrazu sześciu lat hitlerowskiej okupacji, lecz całokształt narracji konstytuującej większościową zbiorową tożsamość, a także model relacji społecznych. Nie do utrzymania okazały się mity założycielskie III RP: mit II RP, mit polskiego państwa podziemnego czy legenda powojennego podziemia antykomunistycznego. W ślad za mitami w zagrożeniu znalazła się podtrzymująca je infrastruktura: relacje międzypokoleniowe w rodzinach, autorytety społeczne (również naukowe), moralny immunitet religii dominującej, instytucjonalna - polityczna i ekonomiczna - pozycja Kościoła rzymskokatolickiego. Zamiast bezprecedensowej szansy emancypacji, wybicia się na mentalną i emocjonalną niepodległość, wyzwolenia przez samoupodmiotowienie większość dominująca, a na pewno decydująca - nie

34 Por. chociażby: J. Tokarska-Bakir Legendy o krwi. Antropologia przesądu, W.A.B., Warszawa 2008; A. Cała Żyd-wróg odwieczny? Antysemityzm w Polsce i jego źródła, Żydowski Instytut Historyczny - Wydawnictwo Nisza, Warszawa 2012.

M. Janion Bohater, spisek, śmierć. Wykłady żydowskie, W.A.B., Warszawa 2009; Honor, Bóg, Ojczyzna, red. M. Rudaś-Grodzka, A. Zawadowska, kierownictwo naukowe M. Janion, Fundacja Odnawiania Znaczeń i Dom Spotkań z Historią, Warszawa 2009; Żebro Mesjasza, red. M. Rudaś-Grodzka, A. Zawadowska, kierownictwo naukowe M. Janion, Fundacja Odnawiania Znaczeń i Dom Spotkań z Historią, Warszawa 2009. 
wyłączając znacznej, a w każdym razie znaczącej części elit - ujrzała na horyzoncie widmo czegoś znacznie gorszego niż koniec świata, a mianowicie: Finis Poloniae.

Piętnaście lat po debacie jedwabieńskiej, usankcjonowane przez najwyższych urzędników państwowych, „kłamstwo jedwabieńskie”36 - będące polską wersją negacjonizmu - stało się w Polsce doktryną oficjalną. Regres do narracji o powszechności pomagania Żydom osiągnął zaś rozmiary niespotykane nawet w 1968 roku. Problemem pierwszoplanowym wydaje się dzisiaj zatem dyskurs o Sprawiedliwych, karze śmierci i żydowskiej niewdzięczności. Mimo to imperatyw krytyki dyskursu spod znaku polskiego świadka Zagłady nie tylko pozostaje w mocy, lecz - w moim przekonaniu - nabiera wręcz nowej aktualności.

Perspektywa rozumiejąca wytyczona przez teorię krytyczną - słusznie kojarzona z jedwabieńskim szokiem narracyjnym i, co ciekawe, starannie i konsekwentnie izolowana od publicznej edukacji - zaczęła być postrzegana jako rodzaj ekstremizmu. W tej sytuacji dyskurs spod znaku polskiego świadka Zagłady - nie zdekonstruowany do końca i nie odrzucony dostatecznie jasno - może awansować, jeśli już nie awansował, do rangi nieskrajnej opcji złotego środka. Dowodzi tego chociażby konceptualizacja Zagłady w Muzeum Historii Żydów Polskich, zaczerpnięta ze środka lat 8o.

Dlatego też istnieje obawa, że - gdy załamie się dyskurs o Sprawiedliwych - grozi nam powrót do dyskursu spod znaku świadka jako wyidealizowanego status quo ante sprzed debaty jedwabieńskiej. Polska tradycja dyskursywnej przemocy pozwoli go wówczas nazwać kompromisem narracyjnym. Krytyka dyskursu spod znaku polskiego świadka Zagłady jest zatem niezbędna, aby pokazać, że - na równi z dyskursem o Sprawiedliwych - jest on wyrazem myślenia życzeniowego i stanowi opcję w pozornej alternatywie, która nie tylko nie pozwala opisać w rozumiejący sposób rzeczywistości Zagłady, ale też blokuje rewizję kultury i społeczno-kulturową zmianę.

36 "Musimy przyjąć, że udawanie, iż nie partycypowaliśmy w Holocauście, nie odpowiada prawdzie historycznej, że taką postawę należy nazywać - per analogiam do «kłamstwa oświęcimskiego» - «kłamstwem jedwabieńskim»" (K. Jasiewicz Pierwsi po diable. Elity sowieckie w okupowanej Polsce 1939-1941. Białostocczyzna, Nowogródczyzna, Polesie, Wileńszczyzna, ISP PAN - Oficyna Wydawnicza Rytm, Warszawa 2001, s. 227). 


\section{Abstract}

\section{Elżbieta Janicka}

THE INSTITUTE OF SLAVIC STUDIES, POLISH ACADEMY OF SCIENCES

Participant-Observers Instead of Witnesses and the Framework Instead of the Fringes: New Concepts in the Description of the Holocaust in the Polish Context

Notions such as"the Holocaust framework" and "participant-observers" are polemical in the context of existing descriptions of the Polish Holocaust, which include terms such as the fringes of the Holocaust and bystanders, whether bystanders are understood as witnesses, onlookers, spectators or gawkers. The social and cultural validity of antiSemitism has made it possible to portray the Polish context of the Holocaust as a panoptical reality and to describe the vast majority as a disciplinary society of participating observers. The concept of "the Holocaust framework" dates the influence of the majority group on the fate of Jews from the beginning of the occupation and in a continuum with pre-war attitudes, discourses and practices. Janicka explains how existing socio-cultural conditions were able to determine the effectiveness of the Holocaust in occupied Poland.

\section{Keywords}

anti-Semitism, the Holocaust, Hilberg's triad, participant observation, panoptical reality, disciplinary society, Jedwabne denial 